\title{
Sciendo
}

\section{THE DEVELOPMENT OF BANDURA MUSIC ART BETWEEN THE 1920s AND 1940s}

\author{
MARYNA BEREZUTSKA \\ Associate professor \\ Department of Folk Instruments \\ M. Glinka Dnipropetrovsk Academy of Music \\ Lyvarna street 10, 49044 Dnipro, Ukraine \\ e-mail: dkdpua@gmail.com
}

\begin{abstract}
Bandura art is a unique phenomenon of Ukrainian culture, inextricably linked with the history of the Ukrainian people. The study is dedicated to one of the most tragic periods in the history of bandura art, that of the 1920s-1940s, during which the Bolsheviks were creating, expanding and strengthening the Soviet Union. Art in a multinational state at this time was supposed to be national by form and socialist by content in accordance with the concept of Bolshevik cultural policy; it also had to serve Soviet propaganda. Bandura art has always been national by its content, and professional by its form, so conflict was inevitable. The Bolsheviks embodied their cultural policy through administrative and power methods: they created numerous bandurist ensembles and imposed a repertoire that glorified the Communist Party and the Soviet system. As a result, the development of bandura art stagnated significantly, although it did not die completely. At the same time, in the post-war years this policy provoked the emigration of many professional bandurists to the USA and Canada, thus promoting the active spread of bandura art in the Ukrainian Diaspora.
\end{abstract}

KEYWORDS: bandura art • bandurists $\bullet$ kobzars

\section{IN T RODUCTION}

The bandura is a unique Ukrainian folk instrument whose history is closely connected with the Ukrainian nation's history. The bandura descends from a more ancient Ukrainian musical instrument the kobza, which was first mentioned in the 14th century (Khotkevych 2013 [1930]: 137). The kobza was an archaic chordophone, with a convex body and a straight bar with three to five strings. Somewhere around that period, every nation had similar musical instruments, which were called lute-like in Europe. They were used by musicians to accompany their songs, many of which recounted significant issues and events for the people. For several centuries the most vital topic for Ukrainians was their freedom because, until 1991, they were not independent. ${ }^{1}$ Folk music instruments develop along with their peoples, each nation developing its instruments according to 
its taste. The body shape of the kobza changed significantly and strings were added, in this way creating the bandura (Khotkevych 2013 [1930]: 159). From the 17th century, the term bandura was often used as a synonym for the kobza, and bandura performers were called kobzars until the middle of the 20th century; quite often the name 'kobzabandura' was used to designate the bandura. The instrument changed, but the semantics of the repertoire remained the same. The whole development of bandura art up to 1991 is the story of its survival under oppression. Bandura players' repertoires either invisibly or obviously reflected the struggle of the Ukrainians for freedom and independence at all times. Dumas (folk epic-lyrical songs of heroic content) and historical songs about Turkish captivity were the main part of bandura players' repertoires in the 16th and 17th centuries, for example, "Duma About the Lament of the Captive" (Tarnawsky and Kilina 1979: 22-29), “Duma About Ivan Bohuslavets" (ibid.: 30-35), "Duma About Samiilo Kishka" (ibid: 46-63), etc. Other dumas were about battles with the Poles in the 17th and 18th centuries: "Duma About of Polish Oppression of Ukraine After the Treaty of Bila Tserkva" (ibid.: 176-179), "Duma About the Battle of Korsun" (ibid.: 148-161), "Duma About Ivan Bohun" (ibid.: 180-183), etc.

Ukrainian-Canadian writer, poet and journalist Paul Crath (and also Pavlo Krat, 1882-1952) wrote in the preface to Songs of Ukraine with Ruthenian Poems:

Moscow, Tartary, Lithuania, Poland, Turkey - what neighbors! - the Hetmans, wars and revolutions - at length the fall of Sich, the last stand of Ukrainian freedom - the whole Ukrainian history was put into song by the Kobzars, the rhapsodists, and if the Ukraine has lost her written history it is still preserved in her historical songs. (Crath 1916: 14)

With the end of the Cossack Age (the period of the Zaporozhian Sich, as it is known to researchers of the history of Ukraine, considered the beginning of the Ukrainian nation) in 1775 , the active struggle for independence ceased, but the bandurists continued to perform the heroic epos until the beginning of the 20th century.

Political authorities always realised the importance of bandura art. Ems Ukaz was active in tsarist Russia between 1876 and 1902, forbidding the publication of all books and song lyrics in Ukrainian and prohibiting the import of such materials. Public lectures, plays, and song performances in Ukrainian were limited, and kobzari-bandurists were also banned (Subtelny 2009 [1988]: 231, 283-284). The most dramatic period of bandura art under the rule of the Bolsheviks is between the 1920s and 1940s, when they methodically destroyed all representations of Ukrainian culture and science (Reid 1999: 116; Subtelny 2009 [1988]: 419).

Bandura art researchers are often accused of politicisation and dramatisation, unacceptable to academic science (Barz and Cooley 1997: 182; Cherems'kyy 1999: 200). However, even the simplest narration of historical facts cannot hide the dramatic nature of the damage that Ukrainian musical culture underwent during the Soviet era. The purpose of academic science in regard to bandura art is exactly to study the features of its development under conditions of political oppression. This research is dedicated not to the Bolshevik suppression of Ukrainian musical culture, but how it had been surviving and developing under the circumstances of that period.

By the beginning of the 1920s concert kobzarship had arisen from traditional kobzarship going on to become the foundation of the academic branch of bandura art. Hnat 
Khotkevych (1928: 28) (1878-1938) called this "the first turning point in the development of kobzar art". He wrote:

Previously, the bandura was a very common instrument among the Ukrainian people. But the years of political oppression and economic powerlessness affected the whole of Ukrainian life, knocking the bandura out of their hands. And it remained only in the hands of a blind brotherhood who were the only ones not breaking the tradition and who, being blind, conveyed to us the national treasure to this day. Dumas, cheerful dances and satirical songs, such was the uncomplicated blind singer's repertoire. But they began to be forgotten under the pressure of the police state. (Ibid.: 24)

Everything changed as soon as the bandura was picked up by sighted people. Initially, they inherited the repertoire based on oral tradition from blind bandurists-kobzars, and then began to perform a new repertoire based on musical notation. Bandurists of the academic branch were engaged in the modernisation and unification of the bandura in order to adapt the instrument for the ensemble performance of musical pieces of any complexity. They created a new training system for professional performers and a new repertoire.

By the beginning of the 1920s, the repertoires of concert and traditional kobzars did not differ from each other, both contained dumas and historical songs that were purely national and expressed the idea of national independence (Kyrdan and Omel'chenko 1980: 121; Lavrov 1980: 114; Cherems'kyy 1999: 27; Mishalov 2013: 74). Associate Professor of political science at Marquette University and author of numerous articles on Soviet nationality policies Kenneth C. Farmer (1980: 117) believes that during that period "folk music, and folk culture in general, [was] also a symbol of national authenticity" both for the Ukrainian people and the Bolsheviks. Therefore, bandura music promoted the unity of the Ukrainian nation; all representatives of bandura art were equally an obstacle to the Bolsheviks, who were planning to build a totalitarian regime (Kuromiya 2007: 109). At the very beginning the Bolsheviks took under tight control all the kobzars-bandurists, mainly using administrative methods. For many years (19181991), the Soviet government tried to dilute the national content of bandura art through censorship and by imposing a repertoire, retaining only its outer shell and turning it into an ideological weapon. The Soviet government made great efforts to ensure that its actions to destroy Ukrainian national culture were not widely publicised, meaning that this period of development of bandura art is the least documented in the scientific literature.

A review of historical, cultural and musicological studies has shown that some aspects of bandura art in certain regions of Ukraine in the first half of the 20th century have already been highlighted. Fedir Lavrov (1980), Borys Kyrdan and Andriy Omel'chenko (1980) studied the historical aspects of the development of kobzarship in Ukraine. Kost' Cherems'kyy (1999) analysed traditional kobzarship in the Kharkiv region under the conditions of the Soviet regime. Viktor Mishalov (2013) investigated the development of the Kharkov school of bandura art. Oleksiy Nyrko (2006) wrote the kobzarship of the Crimea and Kuban. A systematic analysis of bandura art in Ukraine between the 1920s and 1940s has not been performed yet. 
The relevance of the study of the history of bandura art in this period is highlighted by the scarcity of information, as well as by the lack of previous study. Proper systematisation and analysis of bandura art in this period would allow us to reconstruct the general historical picture of the most dramatic period in Ukrainian national music, as well as the ruthless Soviet ideology. For this study, the systematisation of information on bandura art between the 1920s and 1940s was carried out for the first time. A search for sources in multidisciplinary scholarly databases, in electronic repositories, and in libraries and regional archives was made. A search was conducted in Ukrainian, Polish, Russian, English, German and French, using the keywords bandura art, bandurists, and kobzars.

\section{THE DEVELOPMENT OF BANDURA ART BETWEEN THE 1920 s AND 1940s}

It is possible to divide the 1920s-1940s period of bandura art into several parts. Because by the beginning of the 1920s bandura art existed only in the territory of Ukraine (in the Ukrainian diaspora bandura performance was represented only by amateurs), its development was controlled by the Bolsheviks and depended on their goals. Therefore, bandura art and its evolution were determined not by natural development, but through the political will of the Bolsheviks. The first period, 1920-1923, is one of civil war and the struggle of the Bolsheviks to establish power in Ukraine. During the second period, 1923-1929, the Bolsheviks built and strengthened their empire, i.e. the Soviet Union, by contributing to the development of national cultures in the young republics. During the third period, 1929-1941, the Bolsheviks pursued their policy of centralising power and suppressing any manifestations of national freedom, including in literature and art, with the help of their repressive apparatus. The last period, 1941-1949, includes the developments of the Second World War and the post-war years.

\section{0-1923}

By the beginning of the 1920s, the civil war taking place in the territory of the former Russian Empire had not yet ended; the Ukrainian People's Republic (UPR), formed after the revolution of 1917, was fighting back against the Red Army (Adams 1963: 4). Bandurists, as bearers of the ideology of Ukrainian national independence, posed a threat to the Bolsheviks. Researcher of the history of the Soviet Union and Ukraine Hiroaki Kuromiya (2007: 109), writes: "The bandurists were dangerous to Moscow because of their spirit". In February 1918, the Bolsheviks adopted three resolutions: "The socialist homeland is in danger!", "On the shooting of enemies of the Soviet regime at the crime scene" and "About Red Terror" (Melgounow 1926: 56). These decrees ordered punitive organs "to shoot counterrevolutionary agitators, regardless of the form of agitation [...] on the spot" (ibid.: 24). All the bandurists with their national repertoire fell under the effect of these decrees. The punitive organs of the Bolsheviks diligently followed the orders in the territory of the UPR and a month later in March 1918 Ukraine was proclaimed a republic of the Soviets of Worker, Soldier and Peasant Deputies. This did 
not last long as in April 1918 the republic ceased to exist with the arrival of AustrianGerman occupation forces (Sullivant 1962: 49). During the civil war, dozens of bandurists were shot in the territory of Ukraine without trial. In addition, when the Bolsheviks found Ukrainian instruments like the kobza, lyre or bandura in Ukrainian homes they immediately destroyed them (Samchuk 1976: 85; Cherems'kyy 1999: 27). In the early 1920s wandering kobza and bandura players were arrested on charges of begging, tried and sentenced to prison or exiled to concentration camps (Samchuk 1976: 101-103; Cherems'kyy 1999: 32-34). British-American historian Robert Acworth Conquest (1986: 266) (1917-2015) wrote in his book The Harvest of Sorrow: Soviet Collectivization and the Terror-Famine:

At the same time the attack on his national heritage continued. The popular and patriotic culture of the Ukraine had long been sustained in the countryside by the blind bards - the Kobzars, celebrated by [Taras] Shevchenko - who wandered from village to village, earning their keep by singing the old national songs and reciting the national ballads. Thus the peasantries were constantly reminded of their free and heroic past. This undesirable phenomenon was now suppressed.

The Bolsheviks did not make a mistake in their concerns: the bandurists met their expectations. They not only performed old kobzar dumas about the struggle of the Cossacks for the freedom of the Ukrainian people, but also wrote new ones. For example, in 1918 the famous Kharkov bandurist Ivan Kuchuhura-Kucherenko created duma "About the Escape of the Bolsheviks from Ukraine" and in 1926 "On the Death of Symon Petlyura" (Cherems'kyy 2008: 50). Petlyura (1879-1926) was a Ukrainian politician leading Ukraine's struggle for independence following the fall of the Russian Empire in 1917. He became the Supreme Commander of the Ukrainian Army and President of the UPR during Ukraine's short-lived sovereignty of 1918-1921. Both the Bolsheviks and ordinary Ukrainians regarded Petlyura as the successor of the Ukrainian Cossacks in the struggle for Ukrainian independence. The Bolsheviks looked at Petlyura with fear, Ukrainians with hope.

In his book The Voices of the Dead: Stalin's Great Terror in the 1930s Kuromiya (2007: 109-110) emotionally gives a witness account of the events in Ukraine of that time, which allows us to understand the significance of the bandura to Ukrainians:

The bandura is the embodiment of the national spirit. The bandura moves people, and especially so if a person misses his native land, his father and mother, or if a person has a kind of life that is filled with burdens and disappointment, or if there is pain and outrage all around him and the person is in tears.

French scholar of historiography Charles Seignobos (1854-1942) is quoted in the preface of Songs of Ukraine with Ruthenian Poems (1916):

The Ukrainian is a race purely Slav, gay, chivalrous, made thoughtful by its own steppes - a race of poets, musicians, artists who have fixed for all time their national history in the songs of the people which no centuries of oppression could silence. The singers - the kobzars - accompany themselves on the kobza while they sing the glories of the Ukraine. All art with them is national, [...] and which are distinguished for their originality all over the East. (See Livesay 1916: 17) 
In those years, as in the Cossack period, the repertoire of kobza and bandura players was the chronicle of the Ukrainian history. It was thanks to its ideological content that the art of the bandura made a great contribution to the formation of Ukrainian national identity.

\section{3-1929}

Ukraine was ruled by the Bolsheviks from the summer of 1920 until, in December 1922, the Ukrainian Soviet Socialist Republic (USSR) became part of the Soviet Union (Sullivant 1962: 70). Since the Bolsheviks were interested in strengthening and expanding their Soviet empire, they began to pursue a policy of nationalisation, called korenizatsiya (Reid 1999: 120). At this stage, the Communist Party contributed to the development of culture and education in Ukraine and other Soviet republics. In a short time illiteracy was eliminated and hundreds of thousands of Ukrainians learned to read and write in their native language. Ukrainian was used in the work of all state organisations and was taught in schools and universities. This was also the time of active development of Ukrainian literature and poetry (Sullivant 1962: 111). This period was called by scholars "the national and cultural revival of Ukraine" (Kruba and Joukovsky 1986: 33). The Bolsheviks were well aware of the role of bandura art in the history of the Ukrainian people and therefore sought to take it under their control. Professor Mykola Davydov (2005: 12), an outstanding researcher of performance using Ukrainian folk instruments, wrote: "the socialist state in the 1920s decided that folk art could be successfully used as one of the means of ideological influence on the masses". The Bolsheviks perceived ensembles of bandurists as an ideological weapon, control over whom was necessary to the Soviet propaganda system in Ukraine. In 1921, within the Academy of Sciences of the USSR, the Ethnographic Commission was established, which studied the life and work of kobzars (Kyrdan and Omel'chenko 1980: 154). In 1928, a special department was established by the M. V. Lysenko Kiev Musical and Dramatic Institute to prepare a wide range of conductors, directors of choirs, and folk instrument orchestras. According to the Central House of Folk Art, more than 300 amateur kobzar-bandurist associations were formed during this period, in which more than 5,000 people took part (Samchuk 1976: 100).

Soviet newspapers of that period allow us to understand how everything happened. An article titled "From a Beggar's Hands to the Service of Soviet Culture: About Kobza and Kobza Art" was published in the Kiev journal Music in 1927 saying:

Kobza art has been developing actively in Ukraine for the past five years. Now, instead of the single beggar kobzars and several amateurs we have more than ten kobzar ensembles in Kyiv, Kharkiv, Poltava, Odessa, Kryukov, Uman, Konotop, Baryshpol, Myrhorod, Krasnodar, Shishak, Reshetylivka, and others. (Nevermore 1927: 28)

The article ended with the slogan:

From under the fence, from the bazaar to the concert hall, to the club, to the selbud [village club], to the higher music school; from the livelihood of the blind beggar to the means of musical and political education of workers and villagers, this is the 
path of kobza and kobza art, outlined by the Society of Workers and Peasants itself. (Nevermore 1927: 31)

In fact, the path of the kobza-bandura was not outlined by the Society of Workers and Peasants but by the Bolsheviks, and it was a completely different path: from a means to educate people in national dignity and an ideological weapon in the struggle for Ukrainian freedom, to a tool of Soviet propaganda.

The fate of the bandura was decided in the highest instance:

the Higher Music Committee at the People's Commissariat of Education of the USSR decided: 1 . To recognise that kobza and kobza art can be used as a factor in the mass musical and musical-political education of youth; 2 . that for the proper development of kobza art it is necessary to establish factory (mass) production of kobza, which would result in a decrease in its monetary value, to improve the technical facilities of kobza, to organise classes in folk musical instruments and in particular kobza at music universities, take steps to create an ideologically Communist repertoire and strive for the introduction of kobza in instrumental ensembles and folk instrument orchestras. (Nevermore 1927: 30-31)

Mykola Lysenko (1842-1912) and his followers - Kyrylo Stetsenko (1882-1922), Yakiv Stepovyi (Yakymenko) (1883-1921), Mykola Leontovych (1877-1921) and Oleksander Koshyts (1875-1945) - formed a national school of composing at the beginning of the 20th century. A number of works in all existing musical genres ranging from miniatures and arrangements of folk songs to operas and symphonies were created. A national system of music education was developed (Rudnitsky 1963: 119-149; Kruba and Joukovsky 1986: 396). The policy of korenizatsiya contributed to the development of a young national composer's school, which combined the traditions of European music with Ukrainian folklore. Composer Mykola Hrinchenko (1922: 210-211) (1888-1945), supported Lysenko's opinion on "the independence of the Ukrainian folk song from the Russian" and expressed the main tendency of the development of Ukrainian music: "away from Russian music". It is noteworthy that Lysenko reached this conclusion by studying the repertoire of kobza players/bandurists. Polyphonic harmony gives place to a dynamic polyphony that is rooted in the very nature of Ukrainian native song. Thus the active principle in Ukrainian folk music becomes the motive force directing the further development of the style of Ukrainian music (Olkhovsky 1955: 246).

Bandura art was also on the rise. By this time, the raising of bandura performance to an academic level was actively developing: playing bandura was taught to the sighted, the first ensembles of bandura players were created, the first steps were taken to modernise and unify the bandura itself, the first textbooks on playing the bandura were written, original pieces for bandura were created and published, and the first bandura classes were organised. Leading Ukrainian musicians and composers welcomed the academic bandura and predicted a great future for it. The well-known Ukrainian ethnographer Fedir Senhalevych (1925) wrote in the Kiev journal Music:

The bandura, this beautiful instrument, moved from the street and bazaar to the concert hall a long time ago; but the old bandurists are dying, and soon they will probably disappear completely with all the kobzar traditions. The only consolation is that the kobzar itself will not die, because the newest masters, with conservative 
educations, will honourably continue the matter begun by talented old men, the village bandura players.

By the early 1920s, several centres for the development of bandura art were formed in Ukraine, in Kiev, Kuban, Poltava and Kharkov.

In 1918 Vasyl' Yemets', with the help of Hetman Pavlo Skoropadskyi, organised a bandurist capella in Kiev. Together with Yemets', the first string of the capella included only seven people: Mykhailo Teligha, Fedir Dibrova, Fedir Doroshko, Hryhoriy Kopan, Hryhoriy Andriychuk, Oleksa Dzyubenko, Fedir Panchenko. This ensemble gave rise to the lineage of the National Bandurist Capella of Ukraine (Yemets' 1961: 56; Cherems'kyy 1999: 21). In 1923, the Bolsheviks initiated the revival of the capella (in line with the policy of ukrainisation). During the Civil War, many of the members of the capella died, only two of the initial composition of 1918 continued - Doroshko and Kopan (both were shot in 1938) (Kuromiya 2007: 112-114). The Kiev Capella was revived by the Bolsheviks as "a means of political education", like many other ensembles (Olkhovsky 1955: 119). Bandurists toured throughout the country.

Only a few figures are enough to demonstrate the importance of Kobzar ensembles in political education: the State Kiev Kobzars Capella had given more than 1,297 concerts and serviced by more 393,000 listeners by September 1927. The number of concerts arranged by kobzars is increasing every year, and at the same time the turn of their activity is growing. Kobzar ensembles reached the most remote cities and villages of Ukraine and over the past two years have visited Belarus, Moscow, Leningrad, Kuban, and the North Caucasus. (Nevermore 1927: 28)

In Kuban, kobzarship arose in the second half of the 18th century, when many Zaporozhian Cossacks resettled there after the elimination of the Zaporozhian Sich. By the beginning of the 1920s, there were several Kobzar schools in Kuban, in Yekaterynodar and in Pashkovs'ka and Kanevs'ka villages (stanitsas) created by a patron of the kobzar art, 'father of the bandura', Mykola Bohuslavs'kyy (1850-1933) (Yemets' 1961: 114). Yemets', who was invited by Bohuslavs'kyy, made a great contribution to the organisation of schools and popularisation of bandura art in Kuban. These schools gave Ukraine many famous bandura players: Teligha (1900-1942), Dibrova (1880-1919), and others. Between 1923 and 1929, kobzarship spread in Kuban and there were more than 100 bandurists in the region. Bandura became popular among different sectors of population: peasants, student youth and the intelligentsia (Nyrko 2006: 34).

Kharkiv, Slobids'ka Ukrayina or Slobozhanshchyna is one of the oldest centres of bandura art (Doroshenko 1975: 463). The development of bandura art in this region in the 1920s was largely influenced by the well-known populariser of bandura, composer and writer Khotkevych. He organised bandura courses at the Kharkov Music and Drama Institute in 1926. It was an important stage in the development of the bandura:

From that moment on, the bandura took a different course - as an instrument itself, not an appendage for singing. Until that moment, there was nobody and nothing to learn from. The first courses put an end to this. The training course is designed for 3 years, which means that in 1929 the Institute will graduate its first bandura instructors and the requirements for bandura teachers will be met. (Khotkevych 1928: 29) 
Khotkevych wrote dramatic works, songs, and instrumental pieces for bandura, performed Johann Sebastian Bach, Wolfgang Amadeus Mozart, Joseph Haydn on the bandura, and perfected the 'Kharkiv' style of playing, which he outlined in his textbook Bandura School (see Konoplenko-Zaporozhets' 1963: 53; Mishalov 2013: 129). In total, Khotkevych composed 180 musical pieces, 141 of them for the bandura (Kyrdan and Omel'chenko 1980: 70; Mishalov 2013: 292-295). The first kobzar studio was established in 1923 in Poltava (Samchuk 1976: 89). In 1925 the studio received the status of experimental state bandurist capella and was led by bandurist Volodymyr Kabachok (1892-1957) (Kyrdan and Omel' chenko 1980: 69). In 1928 the capella successfully held a concert exam, after which it became known as the First Exemplary Capella of the USSR.

By 1929, the policy of the Bolsheviks towards Ukraine had changed. The leadership of the Russian Communist Party of Bolsheviks ( $\mathrm{RCPb}$ ) had moved toward centralising power and a conflict arose between the leadership of the RCPb and the Ukrainian Bolsheviks. Joseph Stalin's new viceroy Pavlo Postyshev denounced korenizatsiya as a "cultural counter-revolution", the aim of which was to fan "national enmity" and "isolate Ukrainian workers from the positive influence of Russian culture" (Reid 1999: 116; Subtelny 2009 [1988]: 419). This is how the period of the cultural and national revival of Ukraine ended and the next round of the Red Terror, or 'the Executed Renaissance', began. For bandura art, the period of revival was successful only externally. The Bolsheviks facilitated the involvement of broad strata of the population in amateur ensembles of bandura players, thus popularising bandura art. Simultaneously with the development of both amateur and professional groups of bandurists, the Bolsheviks imposed a repertoire in which songs glorifying the Communist Party and the Soviet system predominated. An annual list of musical works allowed by the USSR's Higher Music Committee of the National Committee of the Education (NCE) was published in the Kiev journal Music for the Masses. The list, published in the December issue of the journal, signed by NCE secretary composer Leonid Lisovs'kyy, contains about 100 works, of which only three are for the Kobzar ensemble by Leonid Haydamaka (Khotkevych's student): the Bolshevik song "People Go Forward!", the comic song "About a Deacon" and the lyrical song "Oh, the Fern Bloomed". Five folk songs are for an orchestra of folk instruments (which could include kobzas-banduras) (Lisovs'kyy 1930). Performance of historical, heroic and religious songs was prohibited. From the time of the Soviet triumph everything was subordinated to Stalin's slogan "a culture national in form but socialist in content" and to the implementation of the policy of suppressing any free expression of creative development (Olkhovsky 1955: 248). The Bolsheviks replaced the national content of bandura art with socialist content, forcing kobzars-bandurists to adapt. They created songs glorifying the Communist Party and the Soviet government. Ivan Zaporozhchenko wrote the songs "Glory to the Commune and to Lenin" and "Denikin's Advance"; Pavlo Nosach wrote "Forever with Moscow" and "The Stars of Communism Are Shining"; Yehor Movchan wrote his "Duma about Lenin"; Fedir Kushneryk wrote "About the Pioneer Pavlus" and "Father Lenin"; Yevhen Adamtsevych wrote "On the Death of a Kommunar"; Pavlo Hashchenko wrote "About Lenin" (or "The Sky Stirred"); and Petro Drevchenko wrote "About the Red Army, about Father Lenin and His Loyal Sons" (Kyrdan and Omel'chenko 1980: 64; Cherems'kyy 1999: 28). Many kobzars-bandurists viewed the Bolshevik power with hope, they wrote revolutionary songs, sincerely believing in a better future for Ukrainians under Soviet 
authority. The Bolsheviks organised bandurist performances with a new revolutionary repertoire, forcing bandurists to perform these songs on collective farms and in factories. These pieces were a kind of indulgence for the bandura players, which gave the right to public appearances, where bandurists tried to add songs from the traditional repertoire (Kyrdan and Omel'chenko 1980: 64). The Ukrainian journalist Ulas Samchuk (1976: 64) in his famous book Living String: Bandura and Bandurists, wrote: "at that time Ukraine could not sing what she wanted, but was forced to sing what she was told to sing". The Soviet authorities were interested in the ideological support of bandura players, although the state did not actually contribute to the development of bandura performance. Bandura textbooks and collections of songs written in those years were not published; concert instruments created by enthusiasts did not enter mass production; the bandura was not taught in musical schools (colleges and conservatoires prepared directors of amateur bandura ensembles, but not performers); ensembles of bandura players were not allowed to leave the Soviet Union (Samchuk 1976: 157). The persecution of the bandura players who were not organised into ensembles (and were therefore beyond the control of the Bolshevik government) did not stop even in the 1923-1926 period, the most prosperous years for the Ukrainian culture, when the Bolsheviks supported the policy of Ukrainisation. In fact during this period, many bandurists and kobzars were arrested and exiled to Siberia (Kruba and Joukovsky 1986: 270). Khotkevych (2007a: 88) gives an accurate description of the state of bandura art at this time:

And yet the time will come when the bandura art [...] will develop in a natural historical way. In the meantime, this time has not come, the reason for which is of a larger scale than the influence of one or other person.

Khotkevych saw the natural historical way of the bandura art development and its professional advancement. It can be said that - to paraphrase Stalin's slogan - Khotkevych saw bandura art as a culture national in content and professional in form. Another prominent populariser of bandura art, Yemets', shared his views. Khotkevych sought to preserve and expand the traditional kobzar repertoire by writing music for dumas and historical songs, arrangements for ensemble performance, and by creating new dumas based on classical kobzar themes (Mishalov 2013: 106). Khotkevych expanded the bandurist repertoire to include many historical songs, daily life songs, instrumental folk dances, songs of literary origin, and many Ukrainian folk songs. He improved the instrument, the performing technique and the method of teaching bandura playing (Khotkevych 2007a: 25).

Khotkevych (2007b: 298) produced a tremendous work, driven by a "dream of raising a national musical instrument, with its genius of simplicity, to the level world recognised instrument. An instrument that can claim the title of being a national instrument and the symbol of Ukrainian culture." He was fully aware of the significance of his own work. Summing up his work he wrote in 1934: "I developed a new branch of art - kobzar art. I developed the scientific foundation for it, and raised it from a primitive form performed by blind men to something close to a true art." (See Mishalov 2013: 188) Khotkevych did not exaggerate his merits. The reformations that he carried out with great insistence in bandura art formed the basis of contemporary academic bandura art and determined its progress for decades to come. He managed to realise much himself: he gave life to the ensemble form of bandura performance and the orchestra of Ukrain- 
ian folk instruments; he created a methodology for teaching the bandura; he wrote textbooks and a large original repertoire (both for solo and ensemble). One of Khotkevych's students Leonid Haydamaka (1898-1991) realised and developed the ideas of his teacher, creating the first orchestra of Ukrainian folk instruments and a banduras product workshop (Haydamaka 1928: 6-7; Mishalov 2013: 190). Mishalov wrote:

The contemporary state of this unique art form owes a great debt to Khotkevych, to his work and his talent. It is difficult to imagine in what state contemporary bandura art would be without the contribution of Khotkevych. It certainly would not be the same as what we have today. At the turn of the 20th century, however, it had reached an all-time low, to the point where some thought that it had become extinct. This is what Khotkevych initially came into contact with. He breathed life into the art form and tried to turn the attention of leading Ukrainian intellectuals away from the indifference with which they had watched the decline of this unique musical culture. (Khotkevych 2007b: 243)

Khotkevych published around 15 articles dealing with bandura, its history, the history of kobzars, a textbook for the bandura and a handbook about bandura and its technical potential. According to him:

that's all I have today, this is not enough in comparison with the gigantic literature of world instruments, but it has been created over centuries by many generations [of composers], and here we have the individual production of a person engaged in other affairs who had no other incentive apart from their own inner feelings. Nevertheless, something has been done and now no one dares say that bandura literature [repertoire] is an empty place. New people will come with new energy and share the load. (See Mishalov 2013: 188)

New people with new energy came only in the second half of the 20th century. Only then was the majority of Khotkevych's plan realised: Ukrainian masters made the chromatic bandura, factories began manufactured banduras, bandura textbooks and handbooks were published, bandura classes were started at all conservatories and music colleges in Ukraine.

1929-1941

Andriy Olkhovsky (1955: 249), musicologist and a researcher into the policy of the Bolsheviks, described the development of music in the republics of the Soviet Union as follows:

Soviet art policy in the Ukraine clearly manifested its intention of transforming music into an applied means for political propaganda. In accordance with this policy the forms of organization of Ukrainian musical life were radically changed. A complete and systematic control by the Party was established in all sectors of musical activity. Everything that directly or indirectly served the aims of Bolshevism was encouraged while whatever was opposed to those aims was ruthlessly suppressed. 
The Red Terror affected bandura players too. The Bolsheviks accused all Ukrainian musicians (both composers and performers of folk music) of spreading the Ukrainian 'chauvinist idea'. The persecution of the kobzars-bandurists who wandered through the villages of Ukraine, which had not ceased and in the relatively prosperous korenizatsiya period, intensified. The Bolsheviks tightened control over the organised bandurist capellas and started 'the purges': in 1929 in Poltava bandurists Ivan Myronenko, Ivan Herasymenko, Oleksandr Babak, and Fedir Matviyko were shot for 'counter-revolutionary activity'. The same year, the Poltava Capella was sent for half a year to Donbas with a very high rate of concerts and a limited low-grade repertoire (Mishalov 2013: 158). Bandurists were accused of bourgeois nationalism and anti-Soviet activities for the performance of dumas and historical songs, were arrested and exiled to Siberia. On the same charge, ethnographer Katerina Hrushevs'ka (1900-1943), the daughter of the president of the first independent Ukrainian state in 1917-1918, was arrested and exiled to Vladivostok (and then to Siberia) for publishing a two-volume collection of Ukrainian national dumas (Shapoval 1999). In 1930, 'the Kuban bandura father' Bohuslavs'kyy was arrested on charges of counter-revolutionary activity, dying three years later in Yekaterynodar prison. The famous Kuban bandurist Nyrko (2006: 283-298) compiled an "incomplete list of Kuban bandura players repressed of the 1930s" containing several-dozen names. In January 1930, the Bolsheviks gave the Kiev Capella a new name, The First Exemplary Capella of the People's Commissariat of Education of the USSR, but the funding was extremely unstable, and in 1933 it completely stopped. Many members of the capella were arrested and exiled to the Gulag² (Samchuk 1976: 124-128; Cherems'kyy 1999: 84-110; Pipes 2014).

The years 1932-1933 in Ukraine were marked by a famine. The Communists pursued a policy of collectivisation forcing the creation of collective farms and taking grain from the peasant population (including grain intended for sowing). As a result, several million Ukrainians died of starvation during these years. (Reid 1999: 116; Serbyn 2006) As the Ukrainians resisted, many were shot or exiled to concentration camps (Conquest 1986: 236; Davies and Wheatcroft 2004: 15). In 1930, there were 179,000 people in prison camps; in 1934 510,307; 1,888,571 in 1938, and 1,672,992 people in prison camps in 1941 (Kosyk 1962: 17; Rudnyts'kyy 1963: 53; Vallin et al. 2002: 249; Khlevniuk and Nordlander 2004: 9).

This awful tragedy was reflected in the kobzar "Duma about the Famine", a duma that was added to the Folk Art During the Holodomor and Collectivization in Ukraine collection published in the post-war period (Buhayevych 1993: 17-18). The author of this duma is unknown but it was recorded by the compiler of the collection in 1967 from the words of the kobza player Movchan, the author of the "Duma about Lenin" (ibid.: 16). Many wandering kobzars-bandurists died from famine in 1932-1933 (since the material basis of their existence was exclusively the handouts of the rural population). During this period wandering kobzars (being the representatives of the traditional trend of bandura art) remained the spokesmen of the worldview of the Ukrainian people, which fully determined their repertoire. After the appearance of the "Duma about the Famine" in their repertoire, the NKVD (People's Commissariat for Internal Affairs, the political police and Bolshevik punitive organ) intensified the repressions (MelnyczukMorgan 2010: 115). Bandura players from state capellas fully shared the fate of the Ukrainian people at this time, for example the exhausted and starving bandurists of 
the Poltava Capella toured the villages of the Poltava and Sumy (Sums'kyy) regions (Mishalov 2013: 160).

By 1933, the conflict between the $\mathrm{RCPb}$, which pursued a policy of centralisation of power, and the Ukrainian Communist Party of Bolsheviks (UCPb), which defended the right of the Ukrainian people to self-determination proclaimed by the Bolsheviks and enshrined in the Constitution of the Soviet Union, had reached its peak. The Central Committee of the Russian Bolsheviks accused the Ukrainian communists of bourgeois nationalism, and the punitive organs of the communists purged the leadership of the $\mathrm{UCPb}$ and the government of the USSR. Many Ukrainian Communists were arrested under mysterious circumstances, and in July 1933 the Soviet Minister of Education and patron of bandura players Mykola Skrypnyk committed suicide (Kostiuk 1960: 62). The editor of the Soviet Music journal, Ukrainian musicologist Oleksandr Bilokopytov (1907-1937) posted an article in his journal in 1934 titled, "To Expose and Crush Nationalism on the Musical Front in the Ukrainian SSR". He wrote:

Shameless nationalistic elements made their appearance supported by Scrypnyk in the years 1930-1931. In these years in particular, a number of openly nationalistic textbooks and handbooks were published dealing with various aspect of music. Khotkevychs', [Mykola] Hrinchenkos' and [Valentyn] Kostenkos' nationalist theories became deeply rooted in our musicological work. We'll have to roll up our sleeves and pull the nationalist weeds from the musical field of Soviet Ukraine. It must be done immediately, because otherwise it will be impossible to build a Bolshevik musical culture. (Bilokopytov 1934: 21)

Really Khotkevychs', Hrinchenkos' and Kostenkos' nationalist concepts defended the identity of Ukrainian music only. Khotkevych, according to Bilokopytov (ibid.: 22), intended to "prove that the musical culture in Ukraine should go its own way, not follow Russian musical culture." Hrinchenko was a Ukrainian composer who supported Lysenko's opinion on "the independence of the Ukrainian folk song from the Russian" and expressed the main tendency of the development of the Ukrainian music as "away from Russian music" (ibid.: 24). Kostenko (1895-1960) was a Ukrainian composer and musicologist, author of the book Folk Song and Ukrainian Music (1928), in which he supported the independence of Ukrainian folk music and songs. As Bilokopytov (1934: 27) put it: "Orientation towards Europe and away from Moscow is one of the main positions of Kostenko's nationalist concept".

The Bolsheviks could not let Ukrainian musical culture to go its own way, unlike Russian; they could not recognise the independence of the Ukrainian folk song from the Russian; they could not let Ukrainian music focus on Europe, not Moscow. The independence of Ukrainian music really prevented the building of a Bolshevik musical culture, socialist in content. Moreover, the independence of Ukrainian music from Russian gave rise to the idea of Ukraine's independence from the Soviet Union, something that the Bolsheviks understood well. They, as Bilokopytov (ibid.: 21) urged, really "rolled up their sleeves and began to pull up the national weeds" under the guise of which the best Ukrainian musicians (composers and performers) were decimated.

A real shooting of the Ukrainian cultural revival began: many Ukrainian writers, poets, musicians, composers, journalists, scientists, engineers, teachers, actors, and directors were charged with bourgeois nationalism and plotting an armed rebellion 
against the Soviet Union. Their scientific and literary works were prohibited, they were subjected to arrest, imprisonment, exile and execution. (Farmer 1980: 85; Cherems'kyy 1999: 29; Subtelny 2009 [1988]: 419) The NKVD suddenly uncovered 15 underground anti-Soviet organisations in which Ukrainian cultural figures allegedly took part (Kostiuk 1960: 87). In the 1940s, this period in the history of the development of Ukrainian culture began to be called The Executed Renaissance, the name becoming more widespread after the publication in 1959 of a book of the same name by Yuryi Lavrinenko (1905-1987). Accoridng to Olkhovsky (1955: 247-248),

The outright physical destruction of several of the most important composers (for example, Leontovych, who was killed in 1921 by agents of the secret police), the untimely death of many composers resulting from unbearable repression and exile (for example, Stetsenko and Stepovyi) or emigration (for example, [Fedir] Yakymenko, Koshyts and [Nestor] Horodovenko); the liquidation of many institutions (for example, the Lysenko Musical Institute) - such is the record of Soviet national policy in the field of Ukrainian musical culture.

In December 1933, at a plenary meeting of the All-Ukrainian Committee of the Trade Union of Artists, the communist elite called the Ukrainian folk musical instruments kobza and bandura class-hostile (Cherems'kyy 1999: 118). Thus began the 'legalised' and large-scale destruction of the bandura art. The capellas controlled by the Soviet regime were first subjected to purges, and in 1934 were totally eliminated (Sullivant 1962: 217). There was a real hunt for wandering kobza-bandura players. In 1934, the head of The Poltava Bandurist Capella Kabachok was arrested and exiled to Siberia, and the entire music archive for bandura disappeared along with him. Soon many other members of the capella were arrested. (Samchuk 1976: 124-128; Cherems'kyy 1999: 96). Samchuk (1976: 126) cites the memoirs of kobza player Danilo Kravchenko, who was arrested with many other bandurists in 1935 on charges of armed rebellion against the Soviet Union: "they [the Bolsheviks] were right about the armed rebellion for our banduras themselves were this most armed rebellion". In October 1934, all three state capellas (in Kiev, Kharkiv and Poltava) were eliminated and the remaining performers (those who were not repressed) started working in different choirs (Cherems'kyy 1999: 105).

However, in October 1935, the country's political government decided to restore the state capella. This was necessary to demonstrate the successes of the Soviet state in implementing the policy of 'friendship among peoples'. Thus, from 1935 the Bolsheviks organised annual 'weeks of national art' in Moscow. A ten-day Ukrainian event was planned for March 1936, which could not be held without the State National Bandurist Capella (Martin 2001: 44). Since the majority of members of the Kiev, Poltava and Kharkov Capellas had been repressed, the Bolsheviks formed one single bandurist capella from the remaining free performers (Kochan and Kytasty 1999: 309; Cherems'kyy 1999: 105). The repertoire of the newly created capella was strictly regulated: songs about Stalin the 'rock eagle' and the Communist Party, as well as Ukrainian folk songs of an entertaining character prevailed (Barz and Cooley 1997: 183). However, the newly created Kiev Bandurist Capella was poorly trained. Khotkevych wrote to the director of the State Exemplary Bandurist Capella:

The Capella is known as being 'exemplary' i.e. the best. You set an example for the hundreds of bandurist Capellas in Ukraine. However, only half the performers 
play and the other half hold instrument as stage props. The vocal always drowns out the sound of the bandura. There is no relationship between the music and the vocals. Bandurists plays in unison as our forefathers did. There is nothing to set an example. The capella that wants to set an example should show the provincial centres something new, something that they do not have and something they should try to achieve. You should demonstrate how to harmoniously combine the bandura with the voice, the types of nuance that should be learned and used and the direction to pursue in order to attain them. Then the art of the bandura will not sit in one place, but will move forward. Then in the future more people will come and will raise the level of performance in the central Capella even higher. (Mishalov 2013: 300-301)

In 1936 the Capella was sent on tour to Kazakhstan, Uzbekistan, and Turkmenistan, in 1937 Armenia, Georgia, Moldova, and Kuban. At the same time the NKVD did not stop pursuing bandurists: from 1935 to 1941, five capella directors, four conductors and several performers were arrested and replaced (Samchuk 1976: 126). In 1937, the famous Kharkov bandurist Kuchuhura-Kucherenko was shot as an "enemy of the people" (Cherems'kyy 1999: 59). In 1938 Khotkevych was shot on charges of "bourgeois nationalism" and "plotting an anti-Soviet rebellion" (Barz and Cooley 1997: 182; Mishalov 2013: 189). Despite the overall situation, which was extremely unfavourable to the bandura art, in 1938 participant of the Kiev Capella Mykola Opryshko wrote a textbook called Primary School of Bandura Playing, although the textbook was only published in 1967 (Opryshko and Omel'chenko 1967; see also Kyrdan and Omel'chenko 1980: 73). In 1939, when Stalin forcibly incorporated Western Ukraine into Soviet Ukraine, he dispatched the State Capella there as well as the Red Army. Bandurists sang Ukrainian songs with lyrics by Shevchenko, Ivan Franko and other prominent Ukrainian poets, which proved extremely popular (Polotay 1940: 33; Samchuk 1976: 132-133; Kuromiya 2007: 124). Concerts by the State Bandurist Capella caused a very strong upsurge of national spirit in the Ukrainian population of Western Ukraine, so the political leadership of the USSR was forced to return the Capella to Kiev in 1941. At the beginning of 1941, the ethnographic ensemble of kobzars-bandurists was created under the aegis of the Kyiv State Philharmonic Orchestra. The performers were loyal to the Soviet regime: Movchan, Kushneryk, Nosach and others were songwriters to the glory of Stalin and Vladimir Lenin (Kyrdan and Omel'chenko 1980: 68).

By the end of the 1930s, traditional kobzarship was finally destroyed by the Bolsheviks on the territory of Ukraine, and the oral tradition of transferring the knowledge and skills from one performer to another also perished. The only remaining representatives of the bandura art were the professional bandurist ensembles, the repertoire of which was controlled by the Bolsheviks, making a culture 'national in form but socialist in content' as Stalin would like. In 1940 bandura player and musicologist Mykhaylo Polotay (1899-1989), author of the original "Duma about Lenin", published an article in the journal Soviet Music titled "The Art of the Kobzars of Soviet Ukraine", in which he described the achievements of Soviet bandura art:

The old kobzars in their dumas and songs celebrated the events of their time. Soviet kobzars, with their improved banduras, glorify our Soviet present, the grand events of the Stalin era; they sing in the vast expanses of the Soviet Union in small 
village clubs and in the concert halls of major metropolitan theatres. The Great Stalin Constitution, the heroism of the Civil War, industrial and agricultural construction, socialist competitions on collective farm fields and factory floors, the heroic victories of our glorious Red Army - all that rich and colourful life of our socialist homeland was reflected in the songs of the Soviet kobzars. And we can quite definitely say that there is no such capella, group or separate kobzar who would not sing songs about his beloved leader, about great Stalin. (Polotay 1940: 28)

Polotay was absolutely correct. The only part of the national musical art the Bolsheviks preserved was the scenery, the set, the outer shell. The bandura art during this period turned into a tool of the Soviet regime's propaganda machine and ceased to reflect the worldview of the Ukrainian people.

1941-1949

With the outbreak of the Great Patriotic War, young members of the Capella were enlisted in the Red Army as privates, many of them dying in the first year of the war (Danylo Pika, Opryshko etc.). After the seizure of Kiev by the German army in September 1941, one of the members of the capella Dmytro Chernenko initiated the resumption of its work, and the German occupation authorities allowed the name The Taras Shevchenko Ukrainian Bandurist Chorus. In late 1941-early 1942 the choir performed concerts in the Kiev region, and in summer the German authorities sent the Capella on a tour around Volyn' (Samchuk 1976: 138-141; Hursky and Wytwycky 1980: 35). Under the strong impression of a rise in national spirit among the people of Volyn' caused by the bandurists, the Germans sent the Capella to the Ostarbeiter camp in Hamburg, where all the bandurists worked on a general basis between September and October 1942 (Hursky and Wytwycky 1980: 90). In November 1942, the Germans transferred the Capella to the supervision of the department of culture to be part of German labour front and its Strength Through Joy programme and sent it on a tour of the Ostarbeiter camps in Germany: in 1942-1943 the Capella gave 370 concerts in 168 camps in different cities in Germany over 300 days (Samchuk 1976: 157). In January 1943, Strength Through Joy reported to head office that choirs and music ensembles had been created in several Ostarbeiter camps, and also recommended creating bandurist ensembles and Cossack choirs that could go on tour to other camps (Telka 2008: 124). Until the summer of 1944, the Capella performed in the cities of Western Ukraine, then moved through the Czech Republic and Austria to Germany. By the end of the war, the Capella was in the town of Ingolstadt, which was in the American zone of occupation. Until its departure to America in May 1949, the Capella lived in a displaced persons' camp near Munich, expanded its number of members to include vocalists and constantly gave concerts, mainly in other camps (Rogatinsky 2001: 449). The Capellas' conductor, Hryhory Kytasty, nurtured several generations of young bandura students. His legacy continues through his great-nephew, Julian Kytasty, the artistic director of the New York School of Bandura. 
The Ukrainian diasporas in the US and Canada were formed against the background of the first wave of Ukrainian emigration in the last quarter of the 19th and early 20th centuries. Bandura art was widely represented in all diasporas, formed from this first wave. The Bandurist Society, established in 1916 in Winnipeg, Canada, had 522 members and a 325-volume library (Martynowych 1991: 270). The second wave of emigration was provoked by World War I, the collapse of the Russian Empire and the Bolshevik assumption of power in Ukraine. Therefore, there were a lot of representatives of the creative intelligentsia among these emigrants. The policy of the Bolsheviks, which in the late 1920s became openly anti-Ukrainian with respect to any manifestations of national freedom of thought, naturally resulted in the physical destruction of the figures of Ukrainian culture. This primarily concerned bandurists, the living carriers of the idea of national independence. Provoked by Bolshevik persecution, the emigration of famous performers and teachers of the bandura art gave the Ukrainian diasporas everything they needed to further develop their favorite national musical art.

One of the first famous bandura players and popularisers of the bandura art to move abroad was Yemets', the organiser of The Kiev Bandurist Capella. In November 1919, Minister of Education of the UPR Ivan Ohiyenko sent Yemets' on a foreign tour so that "the bandura performer acquainted European society with the Ukrainian nationals musical instrument" (Yemets' 1961: 70-73). In 1922 Yemets' organised a bandurist capella in Czechoslovakia and bandura schools first in Prague and a little later in Poděbrady. In 1923, in Berlin he published Kobza and Kobzars (Yemets' 1923), soon followed by a musical repertoire collection Our Song (Yemets' 1926). The graduates of Yemets's bandura school (there were more than 60 of them) eventually moved from the Czech Republic to the USA, Canada and Australia and contributed to the development of bandura art in the Ukrainian diasporas of these countries. In 1934, Yemets' moved to France, and in 1936 to the United States; he also toured Canada. In 1946, after eight years of hard work improving the bandura, Yemets' fulfilled his long-held dream of making the national instrument suitable for the performance of classical music: he created the so-called 'double' bandura, with 62 strings, which made it possible for him to perform not only Ukrainian folk songs and dumas, but also the works of Ludwig van Beethoven, Mozart, Pyotr Tchaikovsky, Frédéric Chopin, Lysenko (Yemets' 1961).

Most of the famous representatives of bandura art were in the Ukrainian diaspora after World War II. Primarily The Taras Shevchenko Ukrainian Bandurist Chorus, under the leadership of Kytasty, who in 1949 moved to the United States. Members of the Capella made a great contribution to the preservation of Ukrainian traditions and the popularisation of bandura art on a global scale.

Interestingly, the three world-famous bandura players whose names are associated with the development of bandura art in the Ukrainian diasporas of Great Britain, Australia and the USA, used to perform together in 1943-1944 under the guidance of the famous Lviv bandurist Yuryi Singalevych (1911-1947). Hryhory Bazhul (1906-1988), the founder of bandura art in the Australian Ukrainian Diaspora was a student of Khotkevych and mastered the bandura at the Kharkov Music and Drama Institute. In 1933, he was sentenced to two years imprisonment on charges of bourgeois nationalism and later exiled to Siberia. In 1938, the widow of Khotkevych handed a preserved part of 
the music and literary archive of her husband to Bazhul. Bazhul, who carefully stored the documents for 10 years, took them with him safely to Australia. During World War II Bazhul was forced to move to Western Ukraine, where he joined Singalevych's ensemble. This bandura ensemble included Zinoviy Shtokalko, Volodymyr Yurkevych, Stepan Hanushevsky, Bazhul, Stepan Malyutsa, Hryhory Smyrny and Yaroslav Babunyak. The bandurists performed for the soldiers of the Ukrainian Insurgent Army. At the end of the war, Bazhul emigrated to Germany, where he joined The Taras Shevchenko Ukrainian Bandurist Chorus, and in 1948 moved to Australia, where he organised the Khotkevych Ukrainian Bandurist Ensemble. Bazhul organised a school of bandura art, his students including the world-famous performers and popularisers of the bandura art Victor Mishalov and Petro Deryazhny (Mirosznyk 2009: 116).

As for the other two famous members of Singalevych's ensemble Babunyak (1924-2012) and Shtokalko (1920-1968), they mastered bandura art first in Berezhany (Berezhans'ka) gymnasium, then at Lviv University and, finally, under the direction of Singalevych. At the end of the war, Babunyak was in a prisoner-of-war camp in Italy (Bellaria-Rimini), where there were 10,000 Ukrainians. He organised a choir and a quartet of bandurists there. After his release from the camp, he moved to the UK, where he graduated from a conservatoire. In 1949, he organised the Ukrainian Gomin choir in Manchester, thus making a great contribution to the development of the bandura art in the Ukrainian diaspora of Great Britain (Zheplyns'kyy and Koval'chuk 2011: 9). Shtokalko was sent to a displaced persons' camp in Germany in 1944. After the war he completed his medical education in Munich and defended his thesis on the Biochemistry of Carcinogenesis. In 1952, he emmigrated to the United States and in the 1950s and 1960s wrote the Kobzar Handbook (Shtokalko 1989), which played a major role in the development of the bandura art, not only in the Ukrainian diaspora of the United States, but also in Ukraine. The textbook was repeatedly reprinted after Shtokalko's death and still represents both historical and scientific interest for those involved in bandura art. In addition, Shtokalko collected and processed over 300 Ukrainian folk songs and dumas, which were systematised and published after his death in the form of a collection. Shtokalko, like other members of Singalevych's ensemble, was a virtuoso performer and left a large number of audio recordings of great value. The most famous students of Shtokalko are professor Andriy Horniatkevych and experienced bandura maker Myroslav Dyakovsky (Maystrenko 1981).

\section{CONCLUSION}

Summarising the analysis of the development of bandura art between the 1920s and 1940s, there are several interrelated trends that have predetermined the future of the bandura art for many years to come. The Soviet totalitarian regime in the first decades of its rule used every means at its disposal to take control of Ukrainian national musical art and use it as an ideological weapon. The Soviet authorities actively created ensembles of bandura players, whose repertoire was strictly regulated. Bandurists performed pieces praising the Communist Party and its leaders, while the traditional repertoire of bandurists was prohibited. Wandering bandurists - bearers of the living kobzar tradition - uncontrolled by the Soviet regime, were subjected to harassment: they were shot 
or sent to concentration camps on charges of anti-Soviet activities throughout the whole period under study, many of them died during the Holodomor. Bandurists' state professional ensembles became the only possible form of bandura art in the Soviet Union. During the period of the Red Terror, when the Soviet regime aspired to destroy all manifestations of Ukrainian national freedom, many bandurists from the state capellas were also exiled to the camps or shot despite being completely controlled by the government. The Soviet regime tried to substitute the national content of bandura art with the communist ideology while preserving an outer shell of Ukrainian musical art. Communists contributed in every possible way to the mass development of such 'diluted', low-grade and controlled art to use it for propaganda on Ukrainians in the Soviet Union. Between the 1920s and 1940s, the development of performing on the bandura as a musical art was prevented by the Soviet regime: the bandura was not in mass production in factories, textbooks were not published. The policy of the Soviet regime slowed the development of bandura art for many decades, but did not stop it. Khotkevych (2007a: 22) wrote: "The bandura is an instrument invented by the Ukrainian people and therefore so beloved by them that the Ukrainians brought it to our era through all the hardships of social and political enslavement". Under the difficult circumstances of the 1920s-1940s period, Khotkevych and other associates of bandura art created the foundation of modern bandura art, the ensemble form of bandura performance and an orchestra of Ukrainian folk instruments, the new instrument (bandura incorporating significant design improvements), the original repertoire, new bandura textbooks and handbooks.

The communists' actions provoked the emigration of the Ukrainian intelligentsia, including professional bandura players. Talented performers and teachers of bandura art with the support of the Ukrainian diaspora created schools and bandurist ensembles in Europe, Canada, the USA and Australia that contributed to the popularisation of Ukrainian culture throughout the world. The post-war wave of emigration gave the Ukrainian diaspora of the USA The Taras Shevchenko Ukrainian Bandurist Chorus of North America. Members of this capella were not only famous performers, but also writers, poets, and craftsmen for bandura making. This gave the basis and a powerful impetus to the development of bandura art in the Ukrainian diaspora in geneal, not only in the United States. The bandura players of the Ukrainian diasporas played a special role in preserving the traditional repertoire, which represents the priceless historical heritage of the whole Ukrainian nation. In the 1990s, after the proclamation of Ukrainian independence, both traditional and academic bandura art started its restoration rapidly. The foundations for this revival were laid in the 1920s-1940s period by people who were also committed to the bandura and, therefore, preserved it to the present despite the many hardships of social and political oppression. 


\section{NOTES}

1 The lands populated by Ukrainians (the territory of modern Ukraine) were ruled until the 20th century by the Kingdom of Poland, the Grand Duchy of Lithuania, the Ottoman Empire, the Crimean Khanate, the Polish-Lithuanian Commonwealth, the Russian Empire and AustriaHungary. The Ukrainian Cossacks controlled the part of the Ukrainian lands that was called the Zaporozhian Sich between the 16th and 18th centuries. The Zaporozhian Sich completely occupied the territory of three modern regions of Ukraine (Dnipropetrovsk, Zaporizhzhya, Kherson) and four more partially (Kirovohrad, Mykolayiv, Donetsk, Odesa). By the beginning of the 20th century, most Ukrainian territories were under the rule of the Russian Empire. After the fall apart of the Russian Empire, Ukraine first proclaimed its independence in 1918. The UPR lasted from 1918 to 1921. (Subtelny 2009 [1988]) Ukraine was part of the Soviet Union from 1921 to 1991.

2 The Gulag was the government agency which was in charge of the Soviet network of forcedlabour camps.

\section{A B B RE VIATIONS}

NCE - National Committee of the Education

NKVD - Narodnyy Komissariat Vnutrennikh Del, People's Commissariat for Internal Affairs

$\mathrm{RCPb}$ - the Russian Communist Party of Bolsheviks

$\mathrm{UCPb}$ - Ukrainian Communist Party of Bolsheviks

UPR - Ukrainian People's Republic

USSR - Ukrainian Soviet Socialist Republic

\section{REFERENCES}

Adams, Arthur. 1963. Bolsheviks in the Ukraine: The Second Campaign, 1918-1919. New Haven, CT: Yale University Press.

Barz, Gregory and Timothy Cooley. 1997. Shadows in the Field: New Perspectives for Fieldwork in Ethnomusicology. New York, NY: Oxford University Press.

Bilokopytov, Oleksandr. 1934. Vykryty i roztroshchyty natsionalizm na muzychnomu froni USSR. - Radyans'ka Muzyka 1: 18-44. [Білокопитов, Олександр. 1934. Викрити і розтрощити націоналізм на музичному фроні УССР. - Радянська Музика 1: 18-44.]

Buhayevych, Ihor. 1993. Dozhylasya Ukrayina: narodna tvorchist' chasiv holodomoru i kolektyvizaciyi na Ukrayini. Kyyiv: Ukrayins'kyy pys' mennyk. [Бугаєвич, Ігор. 1993. Дожилася Україна: народна творчість часів голодомору і колективізації на Україні. Київ: Український письменник.]

Cherems'kyy, Kost'. 1999. Povernennya tradytsiyi: Z istoriyi nyshchennya kobzarstoa. Kharkiv: Tsentr Lesya Kurbasa. [Черемський, Кость. 1999. Повернення традиціӥ: 3 історії нищення кобзарства. Харків: Центр Леся Курбаса.]

Cherems'kyy, Kost'. 2008. Kharkivs'kyy kobzar Ivan Yovych Kuchuhura-Kucherenko (1878-1937): yuvileyna zbirka do 130-richchya vid dnya narodzhennya. Kharkiv: Zoloti storinky. [Черемський, Кость. 2008. Харківський кобзар Іван Йович Кучугура-Кучеренко (1878-1937): ювілейна збірка до 130-річчя від дня народження. Харків: Золоті сторінки.]

Conquest, Robert. 1986. The Harvest of Sorrow: Soviet Collectivization and the Terror-Famine. New York, NY: Oxford University Press.

Crath, Paul. 1916. Songs of Ukraina. - Songs of Ukraine with Ruthenian Poems. London; Paris; Toronto; New York, NY: Dent; Dutton, 9-15. 
Davies, Robert and Stephen Wheatcroft. 2004. The Years of Hunger: Soviet Agriculture, 1931-1933. London: Macmillan Publishers Limited.

Davydov, Mykola. 2005. Istoriya vykonavstva na narodnykh instrumentakh (Ukrayins'ka akademichna shkola). Kyyiv: M. P. Chaykovs'koho NMAU. [Давидов, Микола. 2005. Історія виконавства на народних інструментах (Украӥнська академічна школа). Київ: М. П. Чайковського НМАУ.]

Doroshenko, Dmytro. 1975. A Survey of Ukrainian History, edited by Gerus Oleh. Winnipeg: Trident Press Limited.

Farmer, Kenneth. 1980. Ukrainian Nationalism in the Post-Stalin Era: Myth, Symbols and Ideology in Soviet Nationalities Policy. Hague; Boston, MA; London: Martinus Nijhoff Publishers. DOI: https://doi.org/10.1007/978-94-009-8907-8_2.

Haydamaka, Leonid. 1928. Orkestr z ukrayins'kykh narodnykh instrumentiv. - Muzyka Masam 10-11: 6-7. [Гайдамака, Деонід. 1928. Оркестр з українських народних інструментів. Музика Масам 10-11: 6-7.]

Hrinchenko, Mykola 1922. Istoriya ukrayins'koyi muzyky. Kyyiv: Spilka. [Грінченко, M. 1922. Історія української музики. Київ: Спілка.]

Hursky, Jakob and Wasyl Wytwycky. 1980. Tribute to Hrigoriy Kitasty on His Seventieth Birthday. New York, NY: Mayco Graphiks.

Khlevniuk, Oleg and David Nordlander. 2004. The History of the Gulag: From Collectivization to the Great Terror. New Haven, CT: Yale University Press.

Khotkevych, Hnat. 1928. Dva povorotni punkty v istoriyi kobzars'koho mystetstva. - Muzyka Masam 10-11: 24-29. [Хоткевич, Гнат. 1928. Два поворотні пункти в історії кобзарського мистецтва. - Музика Масам 10-11: 24-29.]

Khotkevych, Hnat. 2007a. Bandura ta iyi mozhlyvosti, preface by Viktor Mishalova. Kharkiv; Toronto: Hlas. [Хоткевич, Гнат. 2007а. Бандура та ї можливості, передмова Віктор Мішалова. Харків, Торонто: Глас.]

Khotkevych, Hnat. 2007b. Tvory dlya kharkivs'koyi bandury, preface by Viktor Mishalova. Kharkiv: TO Eksklyuziv. [Хоткевич, Гнат. 2007б. Твори для харківської бандури, передмова Віктор Мішалова. Харків: ТО Ексклюзів.]

Khotkevych, Hnat. 2013 [1930]. Muzychni instrumenty ukrayins'koho narodu. Kharkiv: Savchuk O. О. [Хоткевич, Гнат. 2013 [1930]. Музичні інструменти українського народу. Харків: Савчук O. O.]

Kochan, Alexis and Julian Kytasty. 1999. Ukraine: The Bandura Played on. - World Music 1: Africa, Europe and the Middle East. The Rough Guide, edited by Mark Ellingham, Orla Duane and Vanessa Dowell. London: Rough Guides, 308-312.

Konoplenko-Zaporozhets', Pavlo. 1963. Kobza i bandura. Winnipeg: National Publishers Limited. [Конопленко-Запорожець, Павло. 1963. Кобза і бандура. Вінніпег: National Publishers Limited.]

Kostenko, Valentyn. 1928. Narodna pisnya ta muzyka ukrayins'ka: Styslyy ohlyad. Kharkiv: Rukh. [Костенко, Валентин. 1928. Народна пісня та музика українська: Стислий огляд. Харків: Pyx.]

Kostiuk, Hryhory. 1960. Stalinist Rule in the Ukraine: A Study of the Decade of Mass Terror (19291939). Munich: Institute for a Study of the USSR.

Kosyk, Volodymyr. 1962. Concentration Camps in the USSR. London: Ukrainian Publishers Limited.

Kruba, Emilie and Arcady Joukovsky. 1986. The National and Cultural Renaissance in Ukraine from 1917 to the 1930s. Toronto: CIUS Press.

Kuromiya, Hiroaki. 2007. Ukrainian Bandurists: Singers of National Ballads. - The Voices of the Dead: Stalin's Great Terror in the 1930s. New Haven, CT: Yale University Press, 109-124.

Kyrdan, Borys and Andriy Omel'chenko. 1980. Narodni spivtsi-muzykanty na Ukrayini. Kyyiv: Muzychna Ukrayina. [Кирдан, Борис; Андрій Омельченко. 1980. Народні співці-музиканти на Україні. Київ: Музична Україна.] 
Lavrinenko, Juriy. 1959. The Executed Renaissance: Anthology from 1917-1933: Poetry - Prose - Drama - Essay. Paris: Kultura, Smoloskyp.

Lavrov, Fedir. 1980. Kobzari: Narysy z istoriyi kobzarstva Ukrayiny. Kyyiv: Mystetstvo. [Лавров, Федір. 1980. Кобзарі: Нариси з історії кобзарства України. Київ: Мистецтво.]

Lisovs'kyy, Leonid. 1930. Spysok muzychnykh tvoriv, dozvolenykh do vykonannya Vyshchym muzychnym komitetom pry NKO USSR. - Muzyka masam 9-10: 33. [Лісовський, Леонід. 1930. Список музичних творів, дозволених до виконання Вищим музичним комітетом при НКО УССР. - Музика масам 9-10: 33.]

Livesay, Florence Randal, transl. 1916. Note by Translator. - Songs of Ukraine with Ruthenian Poems. London; Paris; Toronto; New York, NY: Dent; Dutton, 17-20.

Martin, Terry. 2001. The Affirmative Action Empire: Nations and Nationalism in the Soviet Union, 1923-1939. Ithaca, NY: Cornell University Press. DOI: https://doi.org/10.7591/9781501713323.

Martynowych, Orest. 1991. Ukrainians in Canada: The Formative Period, 1891-1924. Edmonton: CIUS Press.

Maystrenko, Levko. 1981. Zinoviy Shtokalko - virtuoznyy hravets' na banduri. - Bandura 3-4: 2-7. [Майстренко, Левко. 1981. Зіновій Штокалко - віртуозний гравець на бандурі. - Бандура 3-4: 2-7.]

Melgounow, Sergey. 1926. The Red Terror in Russia, translated by Terri Fabre. London: JM Dent \& Sons.

Melnyczuk-Morgan, Lesa. 2010. "Remember the Peasantry": A Study of Genocide, Famine, and the Stalinist Holodomor in Soviet Ukraine, 1932-33, As It Was Remembered by Post-War Immigrants in Western Australia Who Experienced It. Fremantle: University of Notre Dame Australia.

Mirosznyk, Anatolij. 2009. How Do You Like Australia? Brookvale: BA Printing \& Publishing Services.

Mishalov, Viktor. 2013. Kharkivs'ka bandura: kul'turolohichno-mistets'ki aspekty henezy ta rozvytku vykonavstva na ukrayins'komu narodnomu instrumenti. Kharkiv; Toronto: Vydavets' Savchuk О. О. [Мішалов, Віктор. 2013. Харківська бандура: культурологічно-містецьькі аспекти генези та розвитку виконавства на українському народному інструменті. Харків; Торонто: Видавець Савчук О. О.]

Nevermore $=$ Tkachenko, Yuriy. 1927. Z ruk zhebraka na posluhu radyans'koyi kul'tury: Pro kobzu i kobzars'ke mystetstvo. - Мuzyka 4: 25-31. [Nevermore = Ткаченко, Юрій. 1927. 3 рук жебрака на послугу радянської культури: Про кобзу і кобзарське мистецтво. Музика 4: 25-31.]

Nyrko, Oleksiy. 2006. Kobzarstvo Krymu i Kubani. L'viv: Spolom. [Нирко, Олексій. 2006. Кобзарство Криму і Кубані. Аьвів: Сполом.]

Olkhovsky, Andriy. 1955. Music under the Soviets: The Agony of an Art. Ann Arbor, MI: Edwards Brothers.

Opryshko, Mykola; Andriy Omel'chenko, eds. 1967. Shkola hry na banduri. Kyyiv: Muzychna Ukrayina. [Опришко, Микола; Андрій Омельченко, ред. 1967. Школа гри на бандурі. Київ: Музична Україна.]

Pipes, Richard. 2014. Lenin's Gulag. - International Journal of Political Science and Development 2 (6): 140-146.

Polotay, Mykhaylo. 1940. Mystetstvo kobzariv Radyans'koyi Ukrayiny. - Radyans'ka muzyka 6: 23-34. [Полотай, Михайло. 1940. Мистецтво кобзарів Радянської України. - Радянська музика 6: 23-34.]

Reid, Anna. 1999. Borderland: A Journey through the History of Ukraine. Boulder, CO: Westview Press.

Rogatinsky, Petro. 2001. Mittenwald 1946-1951. Warren, MI: Society of Former Residents of the Ukrainian Displaced Persons' Camps in Mittenwald, Germany. 
Rudnyts'kyy, Antin. 1963. Ukrayins'ka muzyka: istorychno-krytychnyy ohlyad. Myunkhen: Dniprovs'ka khvylya. [Рудницький, Антін. 1963. Украйнська музика: історично-критичний огляд. Мюнхен: Дніпровська хвиля.]

Samchuk, Ulas. 1976. Zhyvi struny: bandura i bandurysty. Detroit: Drukarnya Petra Maysyury. [Самчук, Улас. 1976. Живі струни: бандура i бандуристи. Детройт: Друкарня Петра Майсюри.]

Senhalevych, Fedir. 1925. Kyyivs'ki vulichni spivtsi. - Мuzyka 4: 196. [Сенгалевич, Федір. 1925. Київські вулічні співці. - Музика 4: 196.]

Serbyn, Roman. 2006. The Ukrainian Famine of 1932-1933 as Genocide in the Light of the UN Convention of 1948. - The Ukrainian Quarterly LXII (2): 181-194.

Shapoval, Iuriy. 1999. Mykhailo Hrushevsky in Moscow and His Death (1931-1934): New Revelations. - Journal of Ukrainian Studies 24 (2): 79-85.

Shtokalko, Zinovii. 1989. A Kobzar Handbook. Edmonton: Canadian Institute of Ukrainian Studies University of Alberta.

Subtelny, Orest. 2009 [1988]. Ukraine: A History. 4th edn. Toronto: University of Toronto Press.

Sullivant, Robert. 1962. Soviet Politics and the Ukraine. New York, NY: Columbia University Press. DOI: https://doi.org/10.7312/sull92910.

Tarnawsky, George and Patricia Kilina, eds. 1979. Ukrainian Dumy: Original Texts. Toronto; Cambridge: Canadian Institute of Ukrainian Studies and Harvard Ukrainian Research Institute.

Telka, Stephen. 2008. Ukrainian Labourers in Nazi Germany, 1939-1945. Ottawa: Carleton University Press.

Vallin, Jacques; France Meslé, Serguei Adamets and Serhii Pyrozhkov. 2002. A New Estimate of Ukrainian Population Losses during the Crises of the 1930s and 1940s. - Population Studies 56 (3): 249-264. DOI: https://doi.org/10.1080/00324720215934.

Yemets', Vasyl'. 1923. Kobza i kobzari. Berlin: Ukrayins'ke Slovo. [Ємець, Василь. 1923. Кобза i кобзарі. Берлін: Українське Слово.]

Yemets', Vasyl'. 1926. Nasha pisnya: Zbirnyk ukrayins'kykh narodnykh dum i pisen' z suprovodom dlya bandury. Praha: Kobzar. [Ємець, Василь. 1926. Наша пісня: Збірник українських народних дум і пісень з супроводом для бандури. Прага: Кобзар.]

Yemets', Vasyl'. 1961. U zoloti 50-richchya na sluzhbi Ukrayiny: Pro kozakiv-bandurnykiv. Hollyvud: Vasyliyan. [Ємець, Василь. 1961. У золоті 50-річчя на службі Украӥни: Про козаківбандурників. Голдивуд: Василіян.]

Zheplyns'kyy, Bohdan and Daryna Koval'chuk. 2011. Ukrayins'ki kobzari, bandurysty, lirnyky. Entsyklopedychnyy dovidnyk. L'viv: Halyts'ka vydavnycha spilka. [Жеплинський, Богдан, Дарина Ковальчук. 2011. Українські кобзарі, бандуристи, хірники. Енциклопедичний довідник. Аьвів: Галицька видавнича спілка.] 